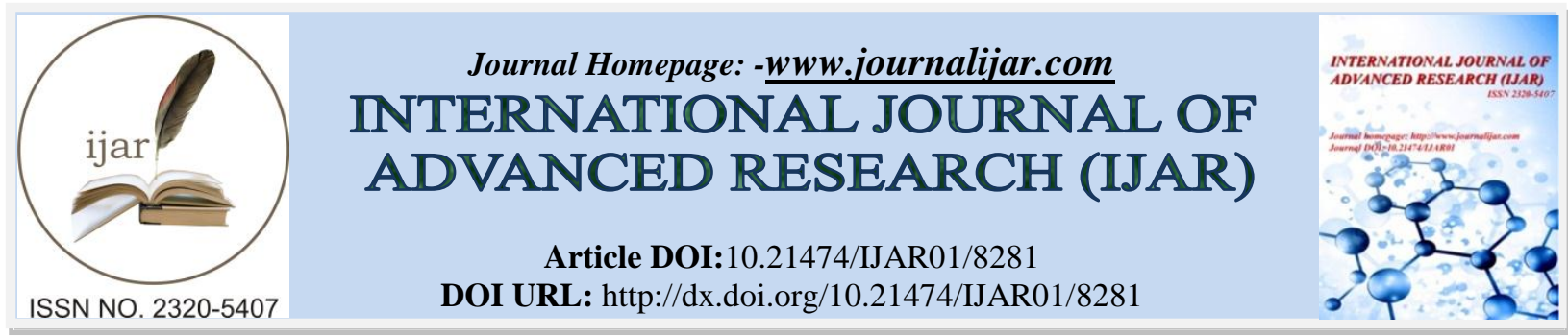

RESEARCH ARTICLE

\title{
STUDY OF MODERNIZATION OF AIR DEFENSE ARTILLERY OF THE INDONESIAN NATIONAL ARMY IN THE FRAMEWORK OF SUPPORTING THE DEVELOPMENT OF AIR DEFENSE POSTURES.
}

\author{
Roma Laksana Yudha ${ }^{1}$, Z. Fanani ${ }^{2}$ and Mukhammad Soleh ${ }^{3}$. \\ 1. Master student of brawijaya university. \\ 2. Postgraduate lecturer of brawijaya university. \\ 3. Postgraduate lecturer of wisnu wardhana university.
}

\section{Manuscript Info}

Manuscript History

Received: 20 October 2018

Final Accepted: 22 November 2018

Published: December 2018

Key words:-

Modernization, Weaponry, ADA, AA

Gun, $57 \mathrm{~mm}$.

\begin{abstract}
In order to develop Air Defense Posture, now, Indonesian Air Defense Artillery (ADA) on the prosess of weaponry modernization that carried out by purchasing new modern weapons to replace the old weaponry which is not feasible to operate, and by developing the ability of old weaponry which is still have feasible to operate. $57 \mathrm{~mm}$ AA Gun system as the part of old weaponry is the most populate Air Defense Artillery weapon that now operated by ADA unit. $57 \mathrm{~mm}$ AA Gun fire unit still have a good condition to operate, but this AA Gun system don't have all ADA function such as detection, identification, tracking, and destruction to air target. Therefore, need to be analized how implementation of weaponry modernization, the support and inhibit factors, and formulation of the proper modernization strategy. This research is carried out by qualitative desciptive metode. The result of this reasearch indicate that the need of $57 \mathrm{~mm}$ AA Gun system modernization is modernization of detection, identification and tracking systems; modernization of AA Gun control system; modernization of C4ISR system; and the modernization of mobilisation system. In order to fill the need, several programs heve been implemented including Defense Research and Development Program (Litbanghan) and Defense Industry's Techlonogy Development Program (Bangtekindhan). So that several Defense Products have been created such as ADA Surveillance Radar, ADA Mobile Command Post, and New Rebuilding of AA Gun Fire Group equipped with Fire Control System. However, to be operated by users, these products still need improvement.
\end{abstract}

Copy Right, IJAR, 2017,. All rights reserved.

\section{Introduction:-}

Background:-

Presently, there are several prominent developments that are of concern in the development of the national defense posture, including the efforts to modernize the Air Defense Artillery (ADA) in the context of building an air defense posture. The development of the global and regional situation that most affected the efforts to develop ADA's

Corresponding Author:-Roma Laksana Yudha.

Address:-Master student of brawijaya university. 
weaponry was by increasing the escalation of Conflict Potential in the South China Sea and the activities and development of Weaponry carried out by members of the Five Power In addition, countries in the Southeast Asia region are currently in the trend of Weaponry modernizing. (Dzikri, 2016)

This situation was affected Indonesia to increase its weapons capabilities. Like several theories about weaponry development which among others were developed by Buzan and Eric Herring (1998) about the dynamics of weaponry written in his book entitled The Arms Dynamic in World Politics that "The dynamics of weaponry refers to the overall pressure that drives actors or in this case the state to acquires new weapons or increases the amount and quality of weapons that have been owned together". This is what drives the development of weapons. The dynamics of weapons are then developed in two models, which are the reaction action model and the domestic structure model. The theory of the reaction action model explains that "Weaponry dynamics are driven by external factors from outside the country. Strengthening military capacity carried out by a country in the face of the threats it faces will have an impact on increasing threats to other countries and encouraging the country to increase its military capacity. "

Efforts to improve weapons capabilities are carried out through a military innovation. Military innovation is a change in the character of warfare which consists of changes in the way organizations organize and carry out military operations (Horowitz, 2010). Although these innovations are not only in the field of technology, they are closely related to technology. According to Horowitz if a military innovation is introduced into an international system, there will be competition between countries which triggers military innovation within the system. These countries will take the innovation to improve the competitiveness of their military capabilities compared to other countries. (Ilman, 2016)

Weaponry development is also influenced by the theory of Revolution in Military Affairs (RMA). The RMA concept is a hypothesis about the development of war in the future, which is often associated with technological developments, organizations (management) and defense doctrines that recommend changes in military concepts. In a certain period of human history a new doctrine, strategy, tactics and technology were needed which caused inevitable changes in the war. In addition, these changes require adaptation to the acceleration of new doctrines and strategies, especially related to the development of modern information, communication devices, or space technology. The development of the internet is also one of the factors that drive the occurrence of RMA, thus shifting the conventional war paradigm to ICT-based (Information and Communication Technology). (Sebastian, 2015)

In Indonesia, according to Miderim (2013), to actualize a strong national defense system it is certainly necessary to modernize existing defense systems to build the Minimum Essential Force (MEF) component in military defense management.In the terms of this weaponry modernization the government has issued a policy as outlined in the Republic of Indonesia Presidential Regulation No. 97 of 2015-2019 General Defense Policy stating that "Modernization Weaponry is carried out in the framework of building the Army force as the main component of defense on land to realize posture ideal of national defense power. The development of the country's defense posture is carried out continuously to realize strength, ability and deployment. The development of a military defense posture is directed at fulfilling the Minimum Essential Force (MEF) so that a strong national defense can be created in order to realize a deterrent effect. "Modernization of weapons is carried out in stages through the replacement and purchase of more new modern and the new formation of weapon units in the entire territory of the Republic of Indonesia, especially at the border, the outermost islands and adapted to the possible threats faced.

As part of the main component of defense, the Air Defense Artillery (ADA) of the Indonesian Army has an important role in national defense. ADA of Indonesian Army has the main task to destroy, eliminate or reduce the usability and results of all forms of enemy air threats in the framework of air defense in the field of national air defense and operations.

In modern conventional conflicts that have occurred, air power acts as a beating force in a conventional war. Air superiority must be achieved in every military campaign so that the ground attack operation phase can be carried out. Besides that, all kinds of operations carried out by the Indonesian Army were severely limited by the threat of air strikes. If the superiority of the air has been controlled by the enemy, the course of the battle becomes not comparable or the maneuverability of the troops becomes very limited, therefore air protection is needed to maintain 
air superiority in the operating field. In order to achieve air superiority, not only the Air Force, but all related elements have a role including the Air Defense Artillery.

Thus, ADA must be able to accelerate the process of achieving air superiority, and must be able to prevent the achievement of air superiority by the enemy. The magnitude of the task load, the ADA of Indonesian National Army as part of the Indonesian National Army's strength that has high and modern capabilities is absolutely necessary.

In carrying out its tasks and functions, the ADA of Indonesia National Army currently operate a variety of weapons systems, which named by Weapon Systems (Sista), Russian-made $57 \mathrm{~mm} / \mathrm{S}-60$ AA Guns, British-made $40 \mathrm{~mm} / \mathrm{L}-70$ AA Guns, 23mm AA Gun guns/GB made in China, German-made 20mm/RH AA Gun, Swedish RBS-70 Missile Cyst, Aster (Poprad Missile Composite with 23/mm Zur AA Gun) made in Poland, TD-2000B (QW-3 Composite Missile with 57mm S-60 AA Gun ) made in China, as well as in the Strategic Plan (Renstra) of Indonesian National Army phase II of 2015-2019, ADA of Indonesian National Army gradually received new weaponry : Starstreak missile made in UK and the Mistral Missile made in France. This was as part of the modernization of the ADA of the Indonesia National Army.

Fulfillment of the ADA of the Indonesia National Army Equipment with modern new equipment is certainly an ideal hope for an increase in TNI capabilities. However, along with the fulfillment process, it needs to be analyzed from another perspective on the 'old' equipment that is still operational and has reliability. Like the Weapon System $57 \mathrm{~mm}$ S-60 AA Gun made in Russia operated by ADA of the Indonesia National Army from 1960 until now. Judging from the population, the $57 \mathrm{~mm}$ AA Gun is the largest weaponry operated by the ADA Army, which is $41 \%$ of the total types of ADA weaponry currently in use.

Thus, it was encouraging the interest of researchers to examine the "Study of Modernization of Air Defense Artillery Armaments of the Indonesian National Army in the Context of Supporting the Development of Air Defense Postures". This research is more focused on the modernization of old Defense weaponry that are still in use today, the $57 \mathrm{~mm}$ AA Gun/ S-60 Weapon System. While the purpose of this study is to analyze the modernization of ADA weaponry, find the factors that support and inhibit, and formulate the right strategy in the modernization of ADA weaponry in order to support the development of an air defense posture.

\section{Research Methods:-}

Looking at the problems regarding the modernization of the ADA of the Indonesia National Army Weaponry in order to support the development of an air defense posture with a focus on research on the modernization of old weapons that are still feasible, which called by the $57 \mathrm{~mm}$ AA Gun Weapon System, the authors used descriptive research methods with qualitative approaches.

In collecting data, researchers used in-depth interviewing methods, unstructured observational methods and documentary methods. The Profound Interview Method is carried out to obtain information in accordance with the research objectives. In interviews, researchers asked questions related to the material that was mastered by Informants about the modernization of ADA of the Indonesia National Army Equipment, especially the 57mm AA Gun. Interviews are carried out repeatedly according to the information needs needed to complete the research. The observation method used is unstructured observations; observation is carried out without observation guide. This technique was taken to supplement the required data relating to observations of the capabilities of the $57 \mathrm{~mm}$ AA Gun Weapon System. This observation method was chosen because in general researchers have known the knowledge of things that will be invaded, while the documentary method is carried out to obtain facts and data stored in material in the form of documentation.

Data analysis in this study was carried out since before entering the field, while on the field, and after returning from the field. Data analysis techniques are principally carried out to process data and analyze data collected into systematic, structured, orderly, and meaningful data. According to Miles and Huberman in Sugiyono (2014: 246253) explained that "activities in qualitative data analysis are carried out interactively and take place continuously until complete, so that the data is saturated". These activities include data reduction, data presentation and conclusion drawing. 


\section{Research Result And Discussion:- Current 57mm AA Gun Weapon System Conditions:-}

Presently, the ADA of the Indonesia National Army Equipment consists of 46 Operational Batteries, of which 19 of them operate $57 \mathrm{~mm} \mathrm{S-60} \mathrm{AA} \mathrm{Gun} \mathrm{(41.30 \% ).} \mathrm{This} \mathrm{number} \mathrm{ranks} \mathrm{first} \mathrm{in} \mathrm{the} \mathrm{ADA} \mathrm{Defense} \mathrm{System} \mathrm{owned} \mathrm{by} \mathrm{the}$ Army. Armament The Russian-made 57mm / S-60 AA Gun used today has two types, $57 \mathrm{~mm} /$ S-60 AA Gun without a Fire Control System (T.AKT) and 57mm/S-60 AA Gun retrofit.

A $57 \mathrm{~mm} \mathrm{S-60} \mathrm{AA} \mathrm{Gun} \mathrm{T.AKT} \mathrm{is} \mathrm{an} \mathrm{original} \mathrm{weapon} \mathrm{from} \mathrm{Russia} \mathrm{that} \mathrm{has} \mathrm{not} \mathrm{been} \mathrm{modernized.} \mathrm{At} \mathrm{first} \mathrm{this} \mathrm{AA}$ Gun had a complete system that was able to carry out the search and tracking functions of the SON-7 radar, as well as automatic control functions in a Fire Group(Satbak) which was controlled by a Fire Control System (AKT). But along with the development of time, the Weapon System in the search, tracking and automatic gun control functions can no longer be used, so this AA Gun can only be used manually by the AA Gun Operator which is then given the term 57mm / S-60 AA Gun T.AKT (Without Fire Control System). Currently 57mm / S-60 T.AKT AA Guns are operational by 10 ADA Units of the Indonesian Army throughout Indonesia, including in the ADA Education Center (Pusdik) with a total of 187 fire unit or 47 fire Group used by 16 ADA batteries.

Whereas the 57mm / S-60 Retrofit AA Gun has been modified in the 1990s in the form of modifications to the electrical control system equipped with the TDAR Radar and Fire Control System. However, the control system is currently inoperable because the electrical system has been damaged and the manual control system has been removed, so that all $57 \mathrm{~mm}$ retrofits cannot be used anymore. $57 \mathrm{~mm} \mathrm{S-60} \mathrm{AA} \mathrm{Gun} \mathrm{/} \mathrm{S-60} \mathrm{Retrofit} \mathrm{operated} \mathrm{by} 5$ ADA Army units with a total of 48 fire unit or 12 fire group (Satbak) used by 4 ADA batteries.

A 57mm / S-60 AA Gun T. AKT, even though it is not equipped with a complete Weapon System but the condition of the AA Gun material is still very strong in carrying out the shooting. This was proven in the implementation of Heavy Weapon Shooting Exercises (Latbakjatrat) both carried out in an integrated manner by Pussenarhanud and carried out by each unit of 57mm S-60 AA Gun. Besides that, the material condition of the AA Gun was maintained due to routine maintenance carried out by ADA's Weapon System Maintenance Unit (Dohar Sista).

However, with the complete absence of the weapons system on these AA Guns, the operational implementation is not optimal. This is felt from the process of deploying $57 \mathrm{~mm} \mathrm{S-60} \mathrm{AA} \mathrm{Gun} \mathrm{units} \mathrm{to} \mathrm{combat} \mathrm{ready} \mathrm{report} \mathrm{units,} \mathrm{and}$ during air defense operations. In the absence of detection and tracking system, detection and tracking are carried out manually. Information on the presence of an air target is obtained from the National Air Defense Command (Kohanudnas) Radar Early Warning received by the Aerial Air Defense (Dahanud) Command Post via communication channels. The information is then drawn on the plan board/plotter board by the officer. This system is still considered very slow considering the rapid movement of air targets. Besides, this system is prone to errors in the presentation of target information from voice news to images. So that a faster and more accurate detection system is needed, namely Local Radar Warning and a data communication system is needed from a more effective early warning radar.

While the 57mm S-60 AA Gun's current control capability can only be controlled manually. This manual control system has several disadvantages including: 1) the ineffectiveness of the use of human labor, because the AA Gun is controlled by 7 operator; 2) Synchronization of AA Gun in Fire Group is carried out manually, so it is very dependent on operator capability; 3 ) the operator's security is insufficient in combat, because the AA Gun operator is in an open field, making it vulnerable to land and air attacks; 4) the slow preparation time of AA Guns until they are ready for combat because the system is used entirely manually with human power.

\section{Analysis of Determination of Modernization Needs for the 57mm AA Gun Weapon System:-}

Analysis of determining the modernization needs of the $57 \mathrm{~mm}$ AA Gun Weapon System was determined based on an analysis of the needs of air defense posture construction, analysis of the condition of the $57 \mathrm{~mm} \mathrm{S-60} \mathrm{AA} \mathrm{Gun} \mathrm{gun}$ system was in accordance with the provisions of the Indonesian National Army general material, and operational analysis of 57mm S-60 AA Guns were faced with the principles of ADA operations.

Although at present the $57 \mathrm{~mm} \mathrm{S-60} \mathrm{AA} \mathrm{Gun} \mathrm{system} \mathrm{has} \mathrm{various} \mathrm{disadvantages,} \mathrm{these} \mathrm{AA} \mathrm{Guns} \mathrm{will} \mathrm{continue} \mathrm{to} \mathrm{be}$ used in the next few decades to support the development of the Air Defense Posture. This is as planned in the Army Strategic Plan, which until 2029 there will be the formation of new ADA units to fill the Minimum Essential Force (MEF). The formation of the new unit qualitatively requires the ADA weaponry to be captured, where the effort is 
carried out through the procurement of new, more modern Weaponry, namely Missiles. Whereas Weaponry currently available, such as a $57 \mathrm{~mm}$ S-60 AA Gun, will be upgraded to improve its capabilities through a modernization program.

The ideal quality of the $57 \mathrm{~mm}$ AA Gun Weapon System in accordance with ADA's needs can be seen from the General Standard Requirements (KSU) of AA Gun of the Indonesian National Army. Where the KSU discussed the material standards used by the Army including among them KSU about the ADA of the Indonesia National Army AA Gun. If faced with the KSU, the shortcomings in the current $57 \mathrm{~mm}$ gun system that need to be upgraded are as follows: 1) improvement in the technology used by weapons systems, especially in electronic and optical technology; 2) the ability to operate at night; 3) detection capabilities through Radar ADA; 4) control system capabilities through the Fire Control System; 5) electrical control capability of AA Gun firing unit; 6) ability to receive target data from the Radar and Fire Control System; 7) Ability to operate in all terrain forms; and 8) Ability to carry out composite operations with other Weapon System.

Then if faced with the ADA principles which include mass, composite, integration and mobility, the operational conditions of the 57mm S-60 AA Gun weapons system are as follows: 1) the 57mm S-60 AA Gun currently meets the bulk principle because there are quite a number of one $57 \mathrm{~mm} \mathrm{S-60} \mathrm{AA} \mathrm{Gun} \mathrm{battery;} \mathrm{2)} \mathrm{even} \mathrm{though} \mathrm{at} \mathrm{present}$ the 57mm S-60 AA Gun has been composite with the Strastreak Missile weapon system, but there are no supporting facilities for carrying out composite operations; 3 ) the integrated operational capability both vertically, namely in the Aerial Air Defense (Dahanud), or horizontally with the Upper Command, is not yet supported by adequate means of communication, computer, command, control, information, surveilance and reconnaissance (C4ISR); and 4) currently $57 \mathrm{~mm} \mathrm{S-60} \mathrm{AA} \mathrm{Guns} \mathrm{are} \mathrm{very} \mathrm{lacking} \mathrm{to} \mathrm{be} \mathrm{able} \mathrm{to} \mathrm{fulfill} \mathrm{the} \mathrm{principle} \mathrm{of} \mathrm{mobility,} \mathrm{because} \mathrm{the} \mathrm{current}$ mobilization system is only with towing vehicles which are considered less effective in the movement and preparation of $57 \mathrm{~mm} \mathrm{S-60} \mathrm{AA} \mathrm{Gun} \mathrm{battles,} \mathrm{so} \mathrm{that} \mathrm{AA} \mathrm{Guns} \mathrm{that} \mathrm{have} \mathrm{self-propelled} \mathrm{capability} \mathrm{.}$

Based on the results of the analysis, it can be determined that the modernization requirements of the 57mm S-60 AA Gun weapons system are as follows: 1) Modernization of the detection, identification and tracking system of air targets; 2) Modernization of the control system; 3) Modernization of the C4ISR system; and 4) Modernization of the mobilization system.

\section{Analysis of the Modernization of ADA's Armament:-}

Efforts to modernize ADA weapons have been carried out in stages through the procurement of more modern New Armaments, namely Strastreak Missiles and Mistral Missiles. Besides that, according to the focus of research on modernization of old weapons that are still feasible to use such as the $57 \mathrm{~mm}$ AA Gun Weapon System; several modernization efforts have been carried out carried out through research and development activities. Since 2006 a Defense Research and Development Program has been carried out by the ADA Center (Pussenarhanud), and the Defense Industry Technology Development Program (Bangtekindhan) of the Indonesian Ministry of Defense. Some of the R \& D activities that have been implemented related with modernization of the 57mm S-60 AA Gun weapons system are as follows:

First, the Dahanud Post Computerized Research and Development Program in 2006-2007, this activity aims to modernize the communication, command and control systems and Information between the Dahanud Command Post and Kohanudnas. The results of the R \& D have succeeded in increasing the capability of the Post with the use of computer technology for the data presentation needs needed by the Post including the air target data received from Kohanudnas. This activity was then continued to be developed through the $2014 \mathrm{R} \& \mathrm{D}$ Program, namely the Designing of Dahanud Mobile Posts. Activities carried out include: developing a communication system for Upper Command and communication in the Dahanud area; development of air target data appearance using the Global Information System (GIS); the development of the ability to display operational data, meteo, shoot obstacles and other data as a means of the Dahanud Commander to make decisions; and development of mobility post capabilities to be able to move places using towing vehicles.

Seeing the importance of the Dahanud Command Post for air defense operations, the results of the 2014 R \& D was continued with the Defense Industry's Development Program (Bangtekinhan) by Ministry of Defense in 2016. However, the results of the Bangtekinhan Program still need to be refined to be operated by ADA units. The series of $\mathrm{R} \& \mathrm{D}$ activities is one of the efforts in the modernization of the C4ISR ADAsystem. 
Second, the Material Engineering Research and Development Program for hydraulic pump and auto-leveling $57 \mathrm{~mm}$ S-60 /T.AKT. The purpose of this activity is to improve the effectiveness of the transporting process and the attitude of combat AA Gun, where this process was previously carried out manually by human power which was then developed into automatic with hydraulic and electric systems. This result of $\mathrm{R} \& \mathrm{D}$ is a solution in repairing hydraulic pumps damaged AA Gun firing unit while increasing the effectiveness and efficiency of AA Guns in the deployment process. This activity was carried out by technicians from the Weapon System Maintenance Unit (Dohar Sista). ADA and this activity were considered quite successful and feasible to be implemented for all the firing unit of AA Guns that exist today. This R \& D activity is one of the efforts to answer the modernization of the 57mm S-60 AA Gun mobilization system, however the expected mobilization system, the 57mm S-60 AA Gun has the ability to self-propelled so that other R \& D activities are needed to increase this capability.

Third, the $57 \mathrm{~mm}$ S-60 Fire Group Rebuilding Program. The purpose of this activity is to activate the $57 \mathrm{~mm}$ S-60 AA Gun control system in one shooting unit (Satbak) which consists of four AA Guns, so that the Satbak can be controlled automatically via AKT or semi-automatic with electric control on each shoot, and still maintain its manual control system. In addition, the newly designed AKT also has the ability to receive target data information from the Dahanud mobile Command Station and the ADA Surveillance Radar from Pussenarhanud. However, before continuing on the Bangtekindhan program, the R \& D results need to be developed for the AKT's ability to track air targets day and night using the Optronic that is currently available. Besides that, it is necessary to develop a security system on AA Gun firing unit through the installation of firing limits, so that the security of AA Gun operators and AKT operators is safe. The R \& D activity is one of the efforts in the modernization of the $57 \mathrm{~mm}$ S-60 AA Gun control system and tracking system.

Fourth, the R \& D Program Modifies Rapier Missile Surveillance Radar as Tracking Radar for AA Gun Fire Group in 2016. The idea of this R \& D activity is to utilize surveillance radar used by the Rapier Missile Weapon System which is currently no longer in use, but after conducting research it turns out electronic components on the Radar the Rapier Missile is already unsuitable for use so that almost all are replaced with new ones. The radar results of the study managed to capture air objects up to a distance of $12 \mathrm{KM}$ and were able to send target data to the Fire Control System as results of R \& D 2016. This R \& D activity was then followed by the ADA Surveillance Radar Design for the 2017 R \& D Program. The 2017 R \& D activity succeeded in creating a radar system capable of detecting air targets up to a distance of 50KM. Then, the captured data can be sent to the Dahanud Mobile Command Post as a result of the 2016 Bangtekindhan Program and to the Gun Control Tool at the 2016 Litbanghan Satbak Meriam. However, there are still shortcomings that need to be improved, namely the detection of captured air targets and the target identification system is friend's aircraft or enemy aircraft (Identification Foe or Friend / IFF). The series of R $\& \mathrm{D}$ activities is an effort in the modernization of the detection system, the introduction and tracking of air targets.

Although the results of the $\mathrm{R} \& \mathrm{D}$ activities have not been perfect, the activity is an answer to the current modernization of the $57 \mathrm{~mm}$ AA Gun Weapon System and needs to be followed up.

\section{Factors that Support and Inhibit Modernization:-}

Supporting factors include the condition of the $57 \mathrm{~mm} \mathrm{S-60} \mathrm{AA} \mathrm{Gun} \mathrm{which} \mathrm{is} \mathrm{still} \mathrm{feasible} \mathrm{to} \mathrm{operate,} \mathrm{and} \mathrm{the}$ Government's support through the Defense Research and Development Program (Litbanghan) and the Defense Technology Development Program (Bangtekindhan) of the Indonesian Ministry of Defense.

The 57mm / S-60 AA Gun have very good material quality, although currently it can only be operated manually. With excellent material quality, there is no concern about material fatigue if the AA Gun is still operated for a decade to come. In general, damage to the $57 \mathrm{~mm}$ corner can be found in the hydraulic pump system. Where the damage can now be repaired by the ADA Weapon Systems Maintenance Unit (Dohar Sista Arhanud). While most shooting systems mechanics still function properly.

The Research and Development (R \& D) program is one manifestation of the government's seriousness in its efforts to improve defense capabilities through the independence of Weaponry. This program has been implemented by Pussenarhanud starting in 2006, where each program that has passed the proposal for activities is always supported by the Program Budget. Meanwhile, the Ministry of Defense's Bangtekindhan Program is a continuation of the R \& D Program, where each product from the $\mathrm{R} \& \mathrm{D}$ results passing the certification test will be continued with this Program to obtain a first article defense product. This program is implemented by the Domestic Defense Industry to perfect the products of the $\mathrm{R} \& \mathrm{D}$ results so that the products are ready for mass production. The Pussenarhanud $\mathrm{R} \&$ 
D results which have been continued with this Program are two activities, namely the Dahanud Mobile Command Post, and the 57mm AA Gun Fire Group (Satbak) Simulator.

Factors that hinder the modernization of the $57 \mathrm{~mm} \mathrm{S-60} \mathrm{AA} \mathrm{Gun} \mathrm{weapons} \mathrm{system} \mathrm{are} \mathrm{as} \mathrm{follows:-}$

First, there has been no ratification of the modernization Roadmap through $\mathrm{R} \& \mathrm{D}$ activities. Planning for integrated R \& D activities for R \& D activities in 2018-2027 has been prepared in the form of a Roadmap for the Pussenarhanud R \& D Program. However, until the end of 2018, the roadmap has not yet been approved and there are still changes. This $\mathrm{R} \& \mathrm{D}$ service roadmap is important to decide and set. This is because there are quite a number of subsystems that need to be developed in one ADA weapon system, so that an integral and mature planning is needed, and there are guarantees to be implemented. In the absence of a roadmap that has been approved by the Army Chief, it is feared that whenever there is a change of leadership there will be a new policy coming out of the planned system, so that the planned integrity of the system cannot be fulfilled.

Second, the lack of mature and measurable $\mathrm{R} \& \mathrm{D}$ planning in accordance with available budget, time and resource support. Both the $\mathrm{R} \& \mathrm{D}$ and Bangtekindhan activities are supported by the budget from the APBN which is provided through the organizational Work Plan (RKA) units that are carried out within one fiscal year. Thus, planning R \& D activities must be mature in order to be able to complete the target of R \& D activities in a timely manner. Some of the causes of the R \& D results are not optimally in accordance with the objectives, namely because planning $\mathrm{R} \& \mathrm{D}$ activities is not considering the time factor and available $\mathrm{R} \& \mathrm{D}$ resources, where at the end of the fiscal year these activities are required to be resolved, while there are some activities that are not optimal due to constraints that were not previously calculated. This can be used as an evaluation material that if $\mathrm{R} \& \mathrm{D}$ activities require complex technology, then these activities must be separated into several stages of $\mathrm{R} \& \mathrm{D}$ activities, so that $\mathrm{R}$ $\& \mathrm{D}$ activities can be more focused and more realistic in accordance with the time and available $\mathrm{R} \& \mathrm{D}$ resources.

Third, the lack of R \& D resources at Pussenarhanud. Pussenarhanud who played a role in carrying out the R \& D activities had a Dirbinlitbang Staff consisting of only 20 staff members. The staff consists of three parts, namely: Staff of Research and Development of Material ADA (R\&D Mat Division); Staff of the ADA Division of Organizational Research and Development, Tactics and Technic (Research and Development of Ortiknik Division) and Staff of the ADA Human Research and Development Section (Human R \& D Division). This staff only has the administrative capacity to carry out R \& D activities and planning planners of R \& D activities according to ADA's obscenity needs. This staff does not have the technical capability in accordance with the R \& D activities needed, especially in the field of ADADirbinlitbang staff requires collaboration with R \& D partners who have technical expertise related to the technology that Pussenarhanud wants to develop, both from Defense Industry (Indhan) and from universities.

Fourth, the lack of synergy between Indhan and Weaponry Users. Synergy between Indhan and Weaponry Users is very important, because after all Indhan Production results will be used by Weaponry Users including Pussenarhanud as the supervisor of ADA Weaponry users. Thus, in developing Weaponry, Indhan must involve users to get input according to their needs. This lack of synergy can be seen from the results of Bangtekindhan's first article Dahanud Mobile Command Post, where the product cannot be used by users because there are several systems that are not yet in line with user needs.

Fifth, the limitations of raw materials/spare parts from the domestic market. The limitation of raw materials/spare parts from the domestic market is a common obstacle faced by domestic industries including the Defense Industry. In terms of modernizing ADA's weapons, the raw materials which are still linked from abroad are those related to metallurgical, electronic and optical technology. Where this is an important requirement in the development of the Weapon System capability. This limitation will greatly affect the independence of the Defense Industry because there is still dependence on foreign countries even if only on raw materials/spare parts. Whereas in the process of carrying out $\mathrm{R} \& \mathrm{D}$ activities this has an effect on the procurement of goods that require considerable time to purchase goods from abroad, thus affecting the implementation of $\mathrm{R} \& \mathrm{D}$ activities which are limited to one fiscal year.

Modernization Strategy for the $57 \mathrm{~mm} / \mathrm{S}-60$ AA Gun Weapon System:-

Based on the results of the analysis of the modernization activities that have been carried out and the analysis of the influencing factors, the modernization strategy can be arranged as follows: 
First, strengthen the determination of needs and Integral modernization planning compiled in a roadmap that was ratified by the Army Chief. With the government policy in the R \& D Program and the Bangtekindhan Program, it has become an opportunity to modernize the $57 \mathrm{~mm}$ AA Gun Weapon System. However, so that this modernization can achieve its objectives in accordance with user needs, then the steps of modernization must be carefully planned, integrated on all systems, and set forth in a Roadmap that is endorsed by the Army Chief of Army.

In carrying out its duties the $57 \mathrm{~mm} / \mathrm{S}-60$ AA Gun does not operate alone but operates in a system, where the AA Gun firing unit is part of a system that performs the function of firing. While the entire ADA's weapons system consists of a system of detection, identification, tracking and destruction. In relation to modernization, the development of this weapons system must be planned in an integrated manner so that the subsystems in it can be integrated in its operation.

With the many subsystems, the importance of ratifying the Roadmap is to avoid the cessation of modernization efforts in the middle of the road due to policy changes once there is a change in leadership. This is very prone to occur, because this modernization process consists of several subsystems, so that it requires quite a long time and process from the R \& D Program, the Bangtekindhan Program to the Production Process by Indhan.

Second, improving the quality of the R \& D Program. As one of the opportunities to achieve the target of modernization, the quality of the $R \& D$ activities carried out must be improved. Improving the quality of $R \& D$ activities is carried out by overcoming the obstacles experienced.

Things that need to be improved are the quality of planning and R \& D activities carried out, taking into account the level of research difficulties faced with the time and available R \& D resources. This is important to be carried out considering that some previous $\mathrm{R} \& \mathrm{D}$ experiences until near the end of the year the implementation of $\mathrm{R} \& \mathrm{D}$ activities has not achieved maximum results due to the constraints that were not previously calculated.

Then, improving the quality of $\mathrm{R} \& \mathrm{D}$ resources because of the limited personnel, facilities and infrastructure in the Pussenarhanud Dirbinlitbang Staff. This increase in R \& D resources can be carried out through efforts to select R \& $\mathrm{D}$ partners who are competent in their fields, both from Universities and from the Defense Industry.

Third, Improve the quality of the Bangtekindhan Program. The Bangtekindhan program as a continuation of the R \& D Program is an important step to perfect the prototype of the $\mathrm{R} \& \mathrm{D}$ results into First Article Indhan products that are ready to be produced according to user needs. Thus, the Defense Industry (Indhan) associated with this Program must have the willingness to increase its capabilities both in innovation and in production.

Then in building a first article product, a synergy between Indhan and Product Users is needed, so that the products produced are truly in accordance with what will be operated by Product Users.

\section{Conclusions And Suggestions:- Conclusions:-}

From the results of the analysis of the research conducted in connection with the modernization of the ADA Army weaponry in order to support the development of air defense postures, especially in the $57 \mathrm{~mm} / \mathrm{S}-60$ AA Gun Weapon System, conclusions can be drawn as follows:

In order to support the development of an air defense posture, the modernization of ADA's weapons, especially the $57 \mathrm{~mm}$ gun system, was absolutely necessary. This is because the $57 \mathrm{~mm}$ AA Gun Weapon System is classified as an old weapon, but still has reliability, and is a weapon with a large enough amount of pollution so it is feasible to develop its capabilities. Modernization is carried out to be able to fulfill the principles of air defense operations which include mass, composite, integrity and mobility. In addition, it is also confronted with the General Requirements of AA Gun ADA Standard of the Army which is a guideline in the selection of material standards that are feasible to be operated by the Indonesian Army. Thus, the forms of capability that need to be developed include: modernization of the detection, identification and tracking system of air targets; modernization of the control system; modernization of the C4ISR system; and modernization of the mobilization system. 
Several attempts at modernization of the $57 \mathrm{~mm}$ S-60 AA Gun weapons system have been carried out by Pussenarhanud as the agency in charge of the Armed Forces of ADA's policy in the Army. The effort was carried out through the Pussenarhanud R \& D Program and the Republic of Indonesia's Ministry of Defense Bangtekindhan Program. From these efforts, there are currently several prototypes of R \& D results, namely: Prototype of the Fire Group of 57mm S-60 AA Gun which is a form of modernization of the control system and tracking system; and the ADA Surveillance Radar Prototype which is a form of modernization of the detection, identification and tracking system of air targets. In the modernization of the C4ISR system, there is now a First Article of Dahanud Mobile Command Post. Whereas in the modernization of the $57 \mathrm{~mm} \mathrm{S-60} \mathrm{AA} \mathrm{Gun} \mathrm{mobilization} \mathrm{system} \mathrm{in} \mathrm{order} \mathrm{to} \mathrm{have} \mathrm{self-}$ propelled capabilities, until now it has not been implemented. However, some of these prototypes still have to be developed to perfect their shortcomings before continuing with mass production, so that they can be used by the ADA Army Unit.

The modernization of ADA weaponry is supported by the condition of the $57 \mathrm{~mm} \mathrm{S-60} \mathrm{AA} \mathrm{Gun} \mathrm{which} \mathrm{is} \mathrm{still} \mathrm{very}$ strong and reliable, besides that it is also supported by Government Policy through the Defense Research and Development Program (Litbanghan) and Defense Industry Technology Development Program (Bangtekindhan) of the Republic of Indonesia Ministry of Defense. However, the program is still hampered by several factors, namely: first, there is no policy that decides integrated planning in the modernization of all $57 \mathrm{~mm} \mathrm{S-60} \mathrm{AA} \mathrm{Gun} \mathrm{weapons}$ systems in the form of a modernization roadmap, thus in the implementation of $\mathrm{R} \& \mathrm{D}$ activities consisting of several systems there are concerns about changing policies when there are changes leader; secondly, limited R \& D resources in Pussenarhanud as the implementers of the R \& D Program, so there is a need for cooperation and synergy with R \& D partners both from Indhan and from universities; and thirdly, there are several raw materials / spare parts in both metallurgical and electrical technology needed in modernization activities that are not available in the domestic market.

The strategies needed to achieve success in the implementation of ADA weaponry modernization are: first, develop a mature and integrated modernization plan in accordance with the needs of the development of ADA's posture, as outlined in a modernization roadmap and obtain guidance from the Army Chief; secondly, continuing the R \& D activities on Prototypes that have not been fully operationally ready and strengthening the results of Bangtekinhan by Indhan before first article is mass produced; third, arrange the planning of $\mathrm{R} \& \mathrm{D}$ activities that are measured in accordance with budget support, available time and resources, so that $\mathrm{R} \& \mathrm{D}$ activities carried out in one fiscal year get realistic results and the maximum in accordance with the objectives of the activity; fourth, increasing synergy between Weaponry users with R \& D partners and Indhan, so that the products used are in accordance with what is needed by users; fifth; improve Indhan's innovation and production capabilities, so as to meet user needs.

As a follow up to the modernization process of ADA weapons currently being carried out, the author provides recommendations for further researchers to carry out research related to the Ability of the Domestic Defense Industry to produce Weaponry according to user needs, especially for ADA Weaponry, so that it can provide input advice on technological independence Defense Industry.

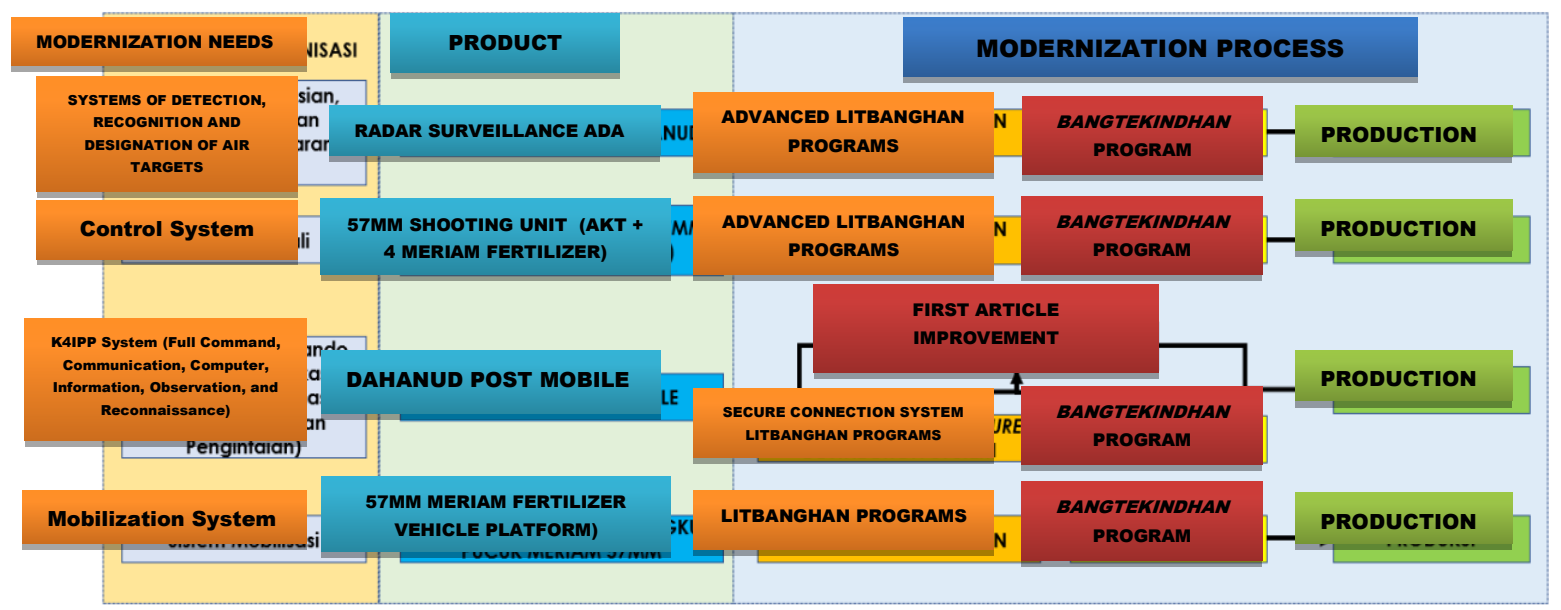

Figure 1:-Illustration of the 57mm Cannon Weapon System Modernization Requirement Scheme, the products needed and the Modernization Process that need to be continued up to the production stage. 


\section{Bibliography:-}

1. Bungin, Burhan. 2007. Penelitian Kualitatif, Komunikasi, Ekonomi, Kebijakan Publik, dan Ilmu Sosial Lainnya. Jakarta : Kencana.

2. Buzan, B. \& Herring, E. 1998. The Arms Dynamic in World Politics. London: Lynne Riener Publisher.

3. Cresswell, Jhon W. 2010. Research Design Pendekatan Kualitatif, Kuantitatif, dan Mixed. Diterjemahkan oleh Achmad Fawaid. Yogyakarta: Pustaka Pelajar.

4. Departemen of The Army. 2000.Field Manual (FM 3-01.11): Air Defense Artillery Reference Handbook.Washington: Departemen of The Army.

5. Heilenday, Frank. 1988. Principle of Air Defense and Air Vehicle Penetration. Washington: Mercury Press.

6. Horowitz, M. C. 2010. The Diffusion of Military Power: Causes and Consequences for International Politics. Princeton: Princeton University Press.

7. Karim, Silmi. 2014. Membangun Kemandirian Industri Pertahanan Indonesia. Jakarta : Kepustakaan Populer Gramedia.

8. Midriem M, Hendri M.S., Ridwan A.S. Vita S., Aditya S.N. Estiko R., dan Agus H. 2013. Kajian Kebijakan Alutsista Pertahanan dan Keamanan Republik Indonesia. Jakarta: LIPI Press.

9. Miles, B. Mathew dan A. Michael Huberman. 1992. Analisa Data Kualitatif. UI Press: Jakarta.

10. Schreer, Benjamin. 2013. Moving Beyond Ambitions? Indonesia’s Military Modernisation. Barton: ASPI.

11. Sloan, Elinor. 2008. Military Transformation and Modern Warfare: A Reference Handbook. Westport: Preager Security International.

12. Sugiyono. 2014.Metode Peneliltian Kuantitatif, Kualitatif dan R\&D.Bandung: Alfabeta.

13. Warden, John A., III. 1994. Air Theory for the Twenty-First Century." In Challenge and Response: Anticipating U.S. Military Security Concerns. Disunting oleh Karl P. Magyar. Alabama: Air University Press.

14. Dowdy, J., Chinn, D., Mancini, M., \& Ng, J. 2014. "Southeast Asia: The next growth opportunity in defense". Dalam McKinsey Innovation Campus Aerospace and Defense Practice Februari 2014.

15. Dzikri, Ilman. 2016. "Negara dan Kapasitas Adopsi Inovasi: Studi Kasus Tranformasi Pertahanan Indonesia Periode 1998-2014”. Dalam Jurnal Politik Internasional Vol. 18 No. 2 Hlm. 131-151, 2016.

16. Hallton, P. Richard. 1997. "Air Power and the Changing Nature of Warfare”. Dalam JFQ/Autumn/Winter 199798, hlm. 39-46, 1998.

17. Hayward, Keith. 2002. "The Globalization of Defence Industries”, Dalam Survival Vol.42. No.2, 1. 2002

18. Hersusanto, Begi. 2012. "Tantangan Diplomasi Perbatasan Republik Indonesia”. Dalam Jurnal Diplomasi. Vol. 4 Nomor.1, 2012.

19. Krepinevich, Andrew F. 1994. "Cavalry to Computer: The Pattern of Military Revolutions," Dalam The National Interest, No. 37, Fall 1994.

20. Montessoro, Francesco. 2014. "Reform And Modernization Of The Indonesian Forces". Dalam Jurnal Analysis No. 268 hlm. 1-8, Juli 2014.

21. Priyono, Eddy. 2011. "Peran dan Kriteria Rudal Darat-Udara dalam Sishanudnas". Dalam Jurnal INDEPT, Vol 1, No.3 Oktober 2011 hlm. 1-7.

22. Rachmat, Angga Nurdin. 2014. "Tantangan dan Peluang Perkembangan Teknologi Pertahanan Global Bagi Pembangunan Kekuatan Pertahanan Indonesia”. DalamJurnal Transformasi Global Vol 1, No 2 hlm. 199-212, 2014.

23. Sebastian, Elly. 2015. Peningkatan Peranan SDM Pertahanan Nasional Guna Menghadapi Perang Generasi Keempat. Dalam Jurnal Pertahanan April 2015, Volume 5, Nomor 1 hlm 109-128.

24. Siagian, Burhanuddin. 2012. "Modernisasi Alutsista TNI AD Dalam Tinjauan Tantangan Tugas Kedepan". Dalam Kajian Triwulan IV SESKOAD, Desember 2012.

25. Sisriadi. 2016. "Pengembangan Postur Pertahanan Militer Guna Mendukung Terwujudnya Poros Maritim Dunia”. WIRA, Volume 59/No. 43, hal.6-17, Maret-April 2016.

26. Subekti, Mayjen TNI. 2012. "Modernisasi Alutsista TNI AD untuk Mencapai Pembangunan Kekuatan Pokok Minimum”.Dalam Jurnal Angkatan Darat YudhagamaVol.32. No.1, Maret 2012.

27. Susanto, Alton E.H, Amien, dan Noegroho. 2006. “Optimalisasi Kemampuan Artileri Pertahanan Udara dalam Mendukung Pertahanan Negara”. Dalam Sosiosains, 19 (4), hal.611-623, 2006.

28. Syaugi. 2014. "Pengembangan Teknologi Menuju Kemandirian Industri Pertahanan". Dalam Majalah Wira. Media Informasi Kementerian Pertahanan Edisi Khusus, hlm. 22-31, 2014.

29. Wijaya, Candra. 2016. “Arah Strategi Alutsista Pertahanan Udara Indonesia”. Dalam Jurnal Angkatan Darat Yudhagama.

30. Ahlawat, Ajay K. 2011. Control of The Air : The Primary Air Power Role. Paper, Air Command And Staff College Air University, Alabama. 
31. Christianson, John. 2016.The Search for Suitable Strategy: Threat-Based and Capabilities-Based Strategies in a Complex World. Monograf, School of Advanced Military Studies U.S. Army Command and General Staff College Fort Leavenworth, Kansas.

32. Luthfi, R. Mokhamad. 2012.Implementasi Revolution in Military Affairs (RMA) dalam Kebijakan Pertahanan Indonesia.Tesis, FISIP Program Pasca Sarjana Ilmu Hubungan Internasional UI, Depok.

33. Metz, Steven dan Keivit James. 1995. Strategy And The Revolution In Military Affairs: From Theory To Policy. U.S. Army War Collage Strategic Studies Institute, Kansas.

34. Nordal, Henrik Olsen. 2013.Thinking of Revolution in Military Affairs (RMA), Toward a Common Understanding of RMA. Tesis, Master of Philosophy thesis in Peace and Conflict Studies Universitetet I Oslo, Oslo.

35. Dirwan, Achmad. Dr,M.Sc.. 2011. Laporan Akhir Tim Pengkajian Hukum tentang Pengembangan dan Pemanfaatan Industri Strategis untuk Pertahanan. Kemenkumham RI, Jakarta.

36. Amperiawan, Gita. 2017. "Terwujudnya Penguasaan Teknologi dan Meningkatnya Kualitas SDM Litbang untuk Mendukung Pengembangan Indhan dalam Rangka Pemenuhan Alpahankam TNI”. Makalah disampaikan pada Rapat Koordinasi Litbanghan Kemhan RI dan TNI di Kemhan RI, Jakarta, 7 September 2017.

37. KKIP. 2017. "Komite Kebijakan Industri Pertahanan (KKIP) \& Pengembangan Industri Pertahanan”. Makalah disampaikan pada Sosialisasi KKIP di Mabesad, Jakarta, 18 April 2017.

38. Wilson, Isiah. 2002. "Strategy, Revisited Analyzing the Shift from a Threat-Based to Capabilities-Based Approach to US Strategic Planning". Makalah ditulis untuk Annual Master Strategist competition (the Grierson Award competition) the U.S. Army Command and Staff College (CGSC), April 2002

39. Kemhan RI. 2015. Buku Putih Pertahanan Indonesia 2015. Jakarta.

40. Keputusan Kasad Nomor Kep/7-XI/1998 Tahun 1998 tentang Organisasi dan Tugas Batalyon Arhanud Sedang $57 \mathrm{~mm} /$ Modifikasi (Orgas Yonarhanudse 57mm S-60/MOD)

41. Keputusan Kasad Nomor Kep/8-XI/1998 Tahun 1998 tentang Organisasi dan Tugas Batalyon Arhanud Sedang 57mm/Tanpa Alat Kendali Tembak (Orgas Yonarhanudse 57mm S-60/T.AKT).

42. Keputusan Kasad Nomor Skep/364/X/2003 Tahun 2003 tentang Buku Petunjuk Operasi Artileri Pertahanan Udara.

43. Keputusan Kasad Nomor Kep/480/XII/2013 Tahun 2013 tentang Naskah Sementara Doktrin TNI AD Kartika Eka Paksi.

44. Keputusan Kasad Nomor Kep/718/XII/2014 Tahun 2014 tentangPetunjuk Induk tentang Arhanud.

45. Keputusan Kasad Nomor Kep/462/VI/2017 Tahun 2017 tentang Petunjuk Teknis tentang Ketentuan Standar Umum Materil dan Bekal TNI AD.

46. Peraturan Kasad Nomor Perkasad/65-02/XII/2013 Tahun 2013 tentang Buku Petunjuk Administrasi Prosedur dan Mekanisme Penyelenggaraan Penelitian dan Pengembangan TNI AD.

47. Peraturan Kasad Nomor 22 Tahun 2016 tentang Organisasi dan Tugas Pusat Kesenjataan Arhanud (Orgas Pussenarhanud) Uji Coba.

48. Peraturan Kasad Nomor 57 Tahun 2016 tentang Organisasi dan Tugas Batalyon Artileri Pertahanan Udara Komposit-3 (Orgas Yonarhanud Komposit-3) Uji Coba.

49. Peraturan Menhan RI Nomor 39 Tahun 2011 tentang Penelitian dan Pengembangan Bidang Pertahanan di Lingkungan Kementerian Pertahanan dan Tentara Nasional Indonesia.

50. Peraturan Menhan RI Nomor 39 Tahun 2016 tentang Program Pengembangan Industri Pertahanan.

51. Peraturan Presiden RI Nomor 97 Tahun 2015 tentang Kebijakan Umum Pertahanan Tahun 2015-2019.

52. Undang-undang No.16 Tahun 2012 tentang Industri Pertahanan.

53. Undang-undang No.34 Tahun 2004 tentang Tentara Nasional Indonesia. 